\title{
From Naive Optimism to Robust Hope: Sustaining a commitment to social justice in schools and teacher education in neoliberal times
}

\author{
Peter McInerney ${ }^{\star}$ \\ University of Ballarat, Australia
}

Drawing on a school ethnography and the voices of graduate students, this paper explores the concept of robust hope with reference to the ideal of social justice in education policy and practice. Although the arguments to support a commitment to social justice in education systems, schools and teacher education programs, are often well articulated, the pedagogical and political strategies to achieve such goals often remain elusive. If we are to reclaim the utopian imagination of socially just schools and egalitarian society we need to move beyond naive optimism to cultivate a notion of robust hope that is praxis oriented and fully cognisant of the complexities, tensions and difficulties associated with the task. "Getting real" in this sense requires the development of conceptual ideas to critique existing social arrangements, a vision of an emancipatory alternative, and a set of political strategies and resources to affect progressive change. Notwithstanding the difficulties of contesting market driven approaches to education, this study reveals that there are "resources of hope" in schools, educational institutions and the broader community to guide teachers and teacher educators in pursuing a goal of socially just schooling.

\section{Introduction}

From time to time we need to remind ourselves that seemingly intractable and oppressive structures can be overturned through collective action on the part of committed individuals, groups and organisations. The overthrow of apartheid in South Africa and the dismantling of the Berlin Wall reveal the power of human agency and the capacity of citizens to challenge the status quo and to bring about progressive social change. Although a large measure of hope may have guided these emancipatory ideals and acted as "a spur to action" (Halpin, 1999, p. 347), hope in itself was insufficient to bring about these changes of this magnitude. In seeking to reclaim a utopian imagination for education it is therefore necessary to distinguish between naive versions of hope which tend to embody "wishful yearning" (Halpin,

* Corresponding author. 70 Alexandra Avenue, Rose Park, South Australia 5067, Australia. 
2003 , p. 2) and undue optimism rather than attainable goals, and the more robust forms which have the possibility of realisation within present social conditions. Halpin (2003) refers to this notion of hope as "utopian realism" because it is framed in a language of practical possibilities. Freire (1994) also reminds us that hope as an ontological need demands an anchoring in practice if it is to become an authentic resource for social transformation. If we are to transform unjust relationships, we need to be guided by a utopian imagination that is grounded in theory and practice, sustained by conviction and moral purpose, and alert to the inherent tensions and difficulties of the task ahead.

In this paper I want to contribute to the discussion on robust hope with particular reference to the pedagogical and political resources to enhance the ideal of socially just schooling. The account has been organised around four major themes. First, I present a brief rationale for sustaining a commitment to social justice that makes explicit the links between the political economy, oppressive social relations and the persistence of educational disadvantage in schools. Second, I provide an illustration of whole school reform for social justice in a disadvantaged school that highlights the role of local agency and transformative pedagogies. Third, I engage in some reimagining of schooling through a framework which incorporates principles, strategies and "resources of hope" (Williams, 1989) to sustain a commitment to social justice in schools, educational policy and the broader community. Fourth, I discuss some of the issues confronting teacher educators as they seek to develop programs and practices for students that have a focus on teaching for social justice.

\section{A Fair Go For All?}

According to popular sentiment, Australians are wedded to the notion of giving people a fair go, but it is abundantly clear from school retention rates and higher education participation figures that an expanded education system has not led to substantial improvements in educational outcomes for working class students, many ethnic minorities and indigenous Australians (Smyth \& Hattam, 2004). Pre-school participation in Australia is low by international standards, especially amongst disadvantaged groups; and students from poorer communities achieve lower results at every level of schooling (Brotherhood of St Laurence, 2005). In spite of the much trumpeted prosperity of the past decade, Australia is a more unequal society than at any stage in its past, with some 700,000 children residing in jobless households and at least one million people living in poverty or extreme economic hardship (Grieg, Lewins, \& White, 2003).

Under neoliberal governance, social policy has taken a back seat to economic policy as State and Federal Governments have moved to privatise State-owned utilities and implement a user-pays approach to many education, health and welfare services. Reflecting on the loss of moral conviction and social direction in Australian politics, human rights activist Frank Brennan (2006, p. 13) commented: 
This Australia Day, I am finding it more difficult to feel the fair go for the young family who have not inherited a home in the city, for the refugee who is still living precariously on a temporary protection visa, for the sick person waiting in the public hospital queue unable to afford sufficient private insurance cover; and for the student who will start working life in debt.

Injustices are not confined to the economic realm. There are disturbing signs of cultural rifts within Australian society following the failure of the Coalition Government to advance reconciliation with indigenous peoples and the rise of anti-Islamic sentiment in the aftermath of September 11. Renewed attacks on the efficacy of multiculturalism, coupled with the appalling treatment of asylum seekers and the abandonment of some longstanding civil liberties in the name of border protection, have engendered a sense of fear of the other in social relations and have heightened racial tensions in Australia. As social institutions, schools are not hermetically sealed from the rest of society. Injustices and oppressive practices visit classrooms on a daily basis and often exacerbate the level of educational disadvantage for oppressed minorities. Moreover, schools which engage in exclusionary practices such as zoning, streaming, inflexible pedagogical practices and discriminatory assessment regimes, are complicit in the reproduction of educational inequalities (Connell, 1993).

The extent of educational disadvantage has been masked by a so-called "educational crisis" (Reid, 2005) which has shifted public attention away from the broader issues of social inequalities to a narrow focus on literacy as the key to improving the life chances of young Australians. The principle of parental choice has become the mantra of education policy, and the patterns of underachievement in schools are once again being attributed to individual, family and cultural deficits rather than structural inequalities. Now, more than ever before, there is a desperate need to reclaim social justice as a major plank in educational reform and social policy development. Although the current political environment appears to be particularly bleak for those seeking to achieve more equitable outcomes for disadvantaged young people, it is important to emphasise that policies are ultimately enacted in the context of schools and are likely to be subjected to varying degrees of resistance, modification and appropriation at the micro-political level. Furthermore, there are committed teachers and school communities who have not abandoned the struggle for socially just curriculum nor given up on the possibility of changing oppressive structures and practices. I now turn to an instance of one such school.

\section{School Reform for Social Justice: Insights from Wattle Plains}

Wattle Plains is the pseudonym for a culturally diverse school serving a low socioeconomic community on the outskirts of an Australian city. Fifty per cent of students qualify for Government support because of family poverty, and more than two-thirds come from linguistically diverse backgrounds, the largest groups being Vietnamese, Cambodian, Polish, Hispanic and Filipino children. About 30 
Aboriginal children attend the school which comprises a child/parent centre, a junior primary section (Reception-Year 3) and an upper primary section (Years 4-7) with leadership personnel working cooperatively across campuses.

When I commenced the study reported, I was aware of the school's longstanding involvement in the Disadvantaged Schools Program. I was particularly interested in observing:

1. The whole school structures and practices which support curriculum development and teachers' learning about social justice and educational disadvantage.

2. How teachers' understandings of social justice were being translated into practice at the classroom level.

The research method involved an extensive phase of participant observation and purposeful conversations (Burgess, 1988) with 12 teachers and senior student members of the school's decision-making forum and was supplemented with photographic records and curriculum documents. Beyond the interpretive nature of the research, I attempted to sustain a socially critical focus by situating participants' accounts within a larger historical, political, economic and symbolic context.

\section{Keeping Social fustice on the Agenda}

At Wattle Plains I witnessed a sense of collective agency and a widely shared conviction that teachers could (and should) challenge unfair practices. One of the remarkable features of the school was the importance attached to social justice, in spite of its demise in State and Federal education policies. "You can't be a successful teacher here without acquiring a social justice headset," I was told. What this involved in practice was a concerted effort on the part of the school to confront unjust educational practices, articulate a vision of a socially just curriculum, and put in place strategies and structures to transform pedagogies.

Teachers discussed the compounding effects of poverty, social class and gender on learning, especially for children from linguistically diverse backgrounds. They saw the need to counteract deficit views of children and their families, to challenge racist behaviours and to affirm the multicultural nature of the community. On the question of political neutrality, a teacher explained: "We're not scared to take a stand for the rights of children at our school". Some of my informants located their empathy for alienated and disenfranchised students within their own ethnic, gendered and/or working class background, and personal experiences of hardship and discrimination. Others spoke of spiritual or humanistic values as a driving force. Many claimed that their understandings of poverty and educational disadvantage were gained through many years of teaching in Priority Project schools. Although participants expressed their understandings of social justice in different ways-some attaching greater weight to cultural and linguistic differences and others to economic factors-there was broad consensus that a concern for social justice should underpin the curriculum. 


\section{Whole School Reform}

A vision of an inclusive, democratic and collaborative school community was contained in a partnership plan developed in consultation with the school community. Implementing the plan involved an interrelated set of structural, cultural and pedagogical strategies and resources (Harradine, 1996) to support the ideal of socially just curriculum. These are described in detail in McInerney (2004) and can be summarised as follows.

- Structural change. Social justice principles guided the school development plan, the workings of all curriculum committees and the $\mathrm{R}-7$ collegiate teams which formed the cornerstone of teachers' professional learning and curriculum development. There was a deliberate effort to match leadership roles and responsibilities with curriculum priorities and social justice goals. Coordinators in the arts, literacy, science and technology worked across the school to facilitate curriculum change and teachers' learning. Students were involved in curriculum decision-making (including the school development plan) through a revitalised student representative council known as the Wattle Plains Decision Makers. An Aboriginal Students Group and Overseas Committee took account of the special concerns of indigenous students and those from linguistically diverse backgrounds. The school community was involved in developing an anti-racism policy and a set of practices to address racist harassment and discrimination.

- Cultural change. Although the structures and planning processes were important to the social justice ethos, they were not as crucial as a school culture that fostered collaborative relationships, success-oriented learning and a culture of debate about teaching and learning. The school adopted the Four Power Model developed by the Brotherhood of St Laurence (1990) that aimed to empower students with respect to resources, relationships, information, communication and decision-making.

Developing audits and making use of data to gauge improvements in student learning for particular cohorts of the school population was standard practice. Unlike the data collected from standardised tests, this information provided a much more robust and contextualised picture of student achievement across the social and cognitive domains of learning. Inclusive and distributive leadership of the kind that I observed was not afraid to step outside the traditional corridors of managerialism in articulating a commitment to social justice and participatory schooling.

- Pedagogical change. Social justice may have been a prime goal of schooling, but the centrality of learning was never lost on my informants. The curriculum was viewed as a conduit to social justice because it was the only tangible means by which students could access knowledge of how to read and act on their world. Such a commitment was expressed in terms of a curriculum entitlement to a broad, balanced and rigorous curriculum that engaged students in worthwhile and 
relevant learning. Students were involved in negotiating significant aspects of their learning, including the criteria for success in assessment tasks. The visual and performing arts became a vehicle for whole school reform that gave students a voice, and incorporated critical literacies and multicultural perspectives into classroom practices, as well as enriching the aesthetic domains of learning. Democratic schools promote dialogic relationships, and in the case of Wattle Plains it was clear that the curriculum tapped into the aspirations and interests of students in order to integrate personal and local concerns with broader social issues.

\section{Living with Dissonance and Ambiguities}

Some caveats are in order at this point. School reform at Wattle Plains was a complex and demanding process that involved long-term planning, short-term goals and a good deal of adjustment and experimentation. It was a project in the making. Although the reforms outlined above had broad community acceptance, not everyone agreed with the curriculum priorities and directions. For example, some parents and teachers felt that the arts were given priority over literacy. Dissent accompanied change. It was apparent that progress had been made towards a collaborative school culture, but developing and sustaining critically reflective practices was a much more difficult task. Perhaps this was to be expected. Contesting market-driven and utilitarian approaches to schooling is a far from comfortable experience, and invariably teachers have to live with a good deal of dissonance and tension when they step outside sanctioned practices.

Although there was recognition on the part of the research participants that the school had taken big steps towards the ideal of socially just schooling, it was tempered with an understanding of the immensity of the task and the numerous impediments to grassroots reform. Not the least of these involved the ambiguities and tensions associated with the school's participation in State-mandated literacy and numeracy testing programs, the difficulties of keeping the education of girls on the agenda, the barriers to the development of critical literacies, and the marketisation pressures on schooling. Teachers had to walk something of a tightrope in struggling to sustain an emancipatory alternative, whilst engaging in a productive and creative way with a neoliberal discourse rooted in functional rationality.

The Wattle Plains experience seems to indicate that successful school reform ultimately depends on a capacity to marginalise the more regressive elements of external reforms or to strategically appropriate them in such a way that they can support socially just curriculum. In other words, making hope practical necessarily involves some pragmatic decisions about what is possible in the current political climate. The task also demands a much broader political canvas. Although local action may be a necessary element in working for socially just schooling, it is difficult to see how the oppressive aspects of neoliberalism can be contested within the perimeters of schools alone. To believe in this possibility is to engage in "romantic localism" (Troyna \& Vincent, 1995, p. 155). Widespread and enduring reform for 
social justice demands collective action across the public education system and society at large, an issue I address in the next section when I consider how we might begin to reconfigure a new commitment to social justice in public education that is grounded in robust hope.

\section{Re-imagining Schooling: Resources of hope}

According to Benhabib (1986), a truly empowering critical social theory consists of the interconnecting moments of critique, norm and utopia. To be of practical and emancipatory value it must do more than assist in understanding the human condition; it must also offer some vision of an alternative to the present arrangements. Above all, it must embody a robust vision of hope that focuses on what is possible with the most extensive resources at hand. In what follows I want to engage in some reimagining of public schooling that draws on Stilwell's (2000, p. 13) analysis of what is required to establish a coherent political and economic alternative to neoliberalism, namely:

1. A critique of the existing situation.

2. A vision of the alternative.

3. Political strategies for change for getting from the present to preferred futures.

4. Organisation in order to work systematically to affect the strategy and bring about desired outcomes.

\section{Critique}

To critique is to discern in a rational and coherent manner what is fundamentally wrong with the current political, economic and cultural conditions of society. As a starting point, we need to name the inequities and gross injustices of the current education reform agenda which have exacerbated the level of disadvantage in communities like Wattle Plains. It is a national disgrace that an affluent country such as Australia spends such a small proportion of its gross domestic product (GDP) on public education yet is able to provide tax breaks for its wealthiest citizens. Since the problems confronting schools are located in the global conditions of society, our analysis must concentrate not just on the local situation but on the global nature of capitalism and its relationship with schooling.

Notwithstanding the damaging impact of neoliberal policies on schools, we have to be careful not to view political doctrines and ideologies as totalising discourses. Critiques of globalisation have a tendency to focus on the deleterious aspects of global competitiveness and free market economics in generating regional poverty and social inequality. They ignored the ways in which supranational networks and communication technologies have enhanced political struggles for human rights and environmental sustainability. At its most oppressive edge, managerialism is preoccupied with efficiency and productivity to the exclusion of human and social benefits. However, as was shown in the Wattle Plains study, school reform can be 
enhanced through systematic planning, efficient use of resources and sound management principles. In a similar vein, concepts like vocationalisation, entrepreneurialism and marketisation can be reframed in socially critical ways to serve, rather than work against, social justice goals.

At a time when there has been a tendency to shift the focus of social injustice away from material inequalities towards cultural recognition, we need to reinvigorate social class as an analytical concept (Smyth, Angus, Down, \& McInerney, 2006) and to reaffirm the debilitating effects of poverty on educational outcomes for many students in public schools. Whatever the merits of the approaches to social justice informed by identity politics and theories of cultural recognition, the political economy needs to be retained as a major explanation of economic inequality (Apple, 1996; Mac an Ghaill, 1996), as it was at Wattle Plains.

Most importantly, we need to show how neoliberal policies have failed disadvantaged schools and their communities, and how they have undermined democratic values and identities, and social relations and notions, such as the "common good" and "civic responsibility". (Giroux, 2006, p. 25)

\section{Vision}

A language of possibility, underpinned by a courageous vision, needs to accompany critique. This is not always easy to enunciate. Proponents of neoliberalism claim TINA-"There is no alternative" (Stilwell, 2000, p. 7)-when it comes to the choice of political and economic doctrines to guide social policy. There can be little doubt that some educators have succumbed to this fatalistic position as evidenced in remarks like "that's the way of the world", "resistance is useless" and "we just have to go along with these policies". However, as shown in the Wattle Plains study, agency when harnessed to collective action has the potential to challenge the status quo and articulate an alternative vision for schooling, at least at the local site.

Halpin (1999, p. 347) argues that "being hopeful, radical and realistic are powerful motivational forces", especially in today's educational context where many critics are justifiably critical of official policy solutions to educational problems. What principles, beliefs and values should guide a vision of socially just schooling? In reimagining current arrangements it might be tempting to revisit the past to recapture the spirit of the Disadvantaged Schools Program, but, as Connell (1998) explains, pursuing an alternative agenda requires more than a resurrection of the notions of redistributive justice. A revitalised vision will need to incorporate responses to the classed nature of society and inequalities arising from the political economy, but it must also be attentive to a politics of identity and claims to recognition of groups excluded or marginalised in traditional schooling (Gale \& Densmore, 2000). In effect, it means taking account of new and emerging social movements and the politics of difference operating around the intersecting and complex categories of poverty, gender, sexuality, ethnicity and disability. 
Visions of democratic and socially just alternatives to market-driven, utilitarian approaches to public schooling are expressed in notions such as "democratic schools" (Apple \& Beane, 1995), "socially just schools" (Kemmis, 1994; McInerney, 2004), "socially critical schools" (Smyth, 1993), "dialogic education" (Shor, 1992), "schooling for critical democracy" (Goodman, 1992), "critical multicultural education" (May, 1994; McLaren \& Giarelli, 1995) and "pedagogically engaged schools" (Smyth \& McInerney, 2006). Though differing in points of emphasis, each of these approaches involves a critical pedagogy that is directed towards emancipatory courses of action. Perhaps this is best encapsulated in Shor's (1996, pp.33-35) ideal of an empowering education that is:

1. Participatory in that it involves students in negotiating the curriculum.

2. Situated in the life worlds and language of students.

3. Critical because it encourages critique and self-reflection.

4. Democratic in that it is constructed mutually by teachers and students.

5. Dialogic insofar as it promotes dialogues around problems posed by students and teachers.

6. Desocialisating in breaking down the culture of silence that often pervades classrooms.

7. Multicultural because it recognises the gendered, racialised and classed experiences of students.

8. Research-oriented.

9. Activist because it is directed towards change.

10. Affective in that it is concerned with the development of feelings as well as social inquiry.

These principles or values offer an exceptionally powerful insight into the practical possibilities of classroom pedagogy-indeed, they might be regarded as the cornerstones of a socially just curriculum.

\section{Political Strategies}

A courageous vision may be a necessary element in reconfiguring a commitment to socially just schooling, but its realisation also demands the selection of appropriate strategies and resources. At Wattle Plains, grassroots reform involved a whole school approach, which addressed in a holistic way the structural, cultural and pedagogical elements of schooling for social justice. However, change was of an incremental nature and proceeded from thoughtful reflection and debate within the community, rather than being hierarchically imposed. Discussing the folly of the rush to reform in the US, Tyack and Cuban (1995) claim that few top-down reformers understand the need to adopt change to local knowledge and needs. They go on to State that there are teachers who "reject fashionable innovations that violate their sense of what their pupils need" (p. 132). As a political strategy, it makes more sense to "graft thoughtful reform onto what is healthy in the present system" (p. 133), rather than starting from scratch and reinventing schools. 
Political advocacy needs to be part of strategic action. It is imperative that educators and school communities pressure Governments of all political persuasions to reinsert social justice principles into all aspects of policy making so that all departments are required to consider the impact of decisions on the social and economic well-being of the community, especially the least advantaged. This necessitates revitalised social justice action plans and specific objectives for improving access, participation and educational outcomes for marginalised and disenfranchised groups. However, such outcomes are impossible without an adequately funded public education system and a reinvigorated curriculum directorate that is more focused on teaching and learning than the development of accountability frameworks.

School reform must go hand-in-hand with community renewal. Writing about the limits of school reform in the US, Berliner (2006) argues that the most powerful policy for improving student achievement is a reduction in family and youth poverty. Because the fates of individual schools and their communities are inextricably linked, the bigger challenge is to set about "building a more economically equitable society" (Berliner, 2006, p. 988). An Australian initiative which holds some promise is the Victorian Government's urban renewal program which incorporates a commitment to community capacity building through an integrated approach to health, welfare and education services in disadvantaged communities (Smyth \& Angus, 2006).

\section{Organisation}

Although there are spaces for school communities and teachers to contest some of the more repressive elements of the current neoliberal discourse, the complexity of the task demands that political action extends well beyond the immediate school community to encompass regional networks, professional associations, education unions and community groups. A major element in school reform at Wattle Plains has revolved around the practices which enhance teachers' learning about the strategies to tackle poverty and other structured inequalities. Such practices highlight the need for more widespread and systemic support for teachers' learning about social justice in teacher education courses, school induction programs and the ongoing professional development of teachers.

Because education cannot be regarded as "the lever for the transformation of society" (Shor \& Freire, 1987, p. 130), the struggle for more socially just schooling needs to extend beyond the classroom to the wider society. By forging links with youth organisations, human rights groups, welfare organisations and community action groups, progressive educators and school communities are more likely to be able to develop the necessary political clout to combat injustices at the local and regional level. Such a stance requires some radical rethinking of teachers' work and conventional school/community relationships-especially those which are commonly promoted in the marketised version of schooling. Conceived of in this way, 
school/community partnerships might extend the links beyond vocationalism and the world of work to an alliance working for more socially just outcomes in schooling - a necessary strategy in tackling the numerous and complex social, environmental and economic issues that are not contained within the perimeters of the school.

The focus in this paper has been on school-based reforms and local practices that promote teachers' learning about social justice and education. However, resourcing a pedagogy and politics of hope is a complex task that requires support and commitment from all those engaged in the professional development of teachers. In the next section, I want to consider some of the dilemmas and possibilities confronting teacher educators engaged in this task.

\section{Learning to Teach for Social Justice}

Cochran-Smith (1999) claims that the most important goals of teacher education programs are social responsibility, social change and social justice. In a similar vein, Nieto (2000) argues that equity needs to be placed at the forefront and centre of teacher education. If prospective teachers are to play a more transformative role in contesting inequitable schooling arrangements, they need to develop a knowledge and understanding of the moral and political purposes of education, the social context of schooling, and the relationships between social class, "race" and gender in the production of educational disadvantage (Lingard, 1994). These issues, along with programs focusing on the needs and aspirations of indigenous Australians and strategies to promote the development of critical literacies, should be placed at the centre of teacher education programs and not consigned to the periphery.

Although these views are probably shared by many teacher educators, they have not found favour with conservative policy makers. Increasingly it appears that teachers' work is being construed in narrow, instrumental and apolitical ways; a conception that is reinforced through "teacher proof" curriculum, competency frameworks, standardised testing regimes and other accountability measures that seem more intent on controlling teachers than enhancing their creative energies and talents. According to Giroux (2005) a "conservative assault" and "new authoritarianism" has worked its way into teacher training institutions with calls for more practice-based training and an emphasis on courses which focus on teaching skills and competencies, rather than social activism, critical literacies and concerns for social justice.

These technicist conceptions of teachers' work came to the fore when a group of student teachers presented a submission on teacher education on behalf of the Social Justice Research Collective at Flinders University to a Standing Committee of the House of Representatives (Commonwealth of Australia, 2005). The session opened with an invitation for the students to discuss what they liked about their undergraduate courses and what might have been improved. Alana Murphy said that students in her course had received "a strong intellectual training" which had 
enabled them to "interpret and understand the place of education within the broader social context". Louise Pyman stated that a concern for social justice was the main reason she enrolled in the course and she planned to teach on the Indigenous lands schools. Hazel Greatbanks commented on the value of the unit on Aboriginal and Torres Strait Islander education and both Terri King and Jacqueline Dyte remarked on the importance attached to social justice in their undergraduate studies.

Following a discussion about the practicum and organisational aspect of teaching, panel member Michael Ferguson challenged the students' conceptions of their roles as agents of social change and questioned their views about the political nature of teaching. Ferguson began:

I am a bit curious about Louise and Alanna's comments relating to social justice. You said something which really struck me: that schools are not apolitical and that schools are places where you have great influence and change society. I have not heard that for a while, in the sense that you are actually canvassing that in your future lives as career teachers you see yourselves as agents of social change. You did not say-although you probably do feel it - that you felt your primary function would be to help young people to learn and achieve their potential.

The fact that you did not mention that rings an alarm bell for me. What is it about the Flinders course which propels you in that direction, and how appropriate do you think it is to see yourself in that light?

Louise defended her views with reference to the marginalisation of Indigenous students and the need for major social change to improve educational outcomes and Alana translated her theory of social change into practice as follows:

On my final practicum I encouraged every one of the 58 Year 7 and 8 students I had to go out and do one day or two days of volunteering in the community, such as volunteering for Meals on Wheels or childcare centres, cleaning up rubbish and a variety of things. I would say that that is encouraging students to create positive social change or to make a difference. I had an extremely positive response from all the parents. They thought it was wonderful that their kids were getting out there and doing something real. Being an agent of positive social change does not necessarily have to mean that we are back to the protest era and we are putting words in the mouths of our students. ... That is not what we are about. We are enabling our students to do something real and to do something that has a purpose for them and the community that the school is located within.

Whitehead (2007) noted that the student teachers were "disruptive voices" in their refusal to embrace the rather narrow technicist training model of classroom management that seemed to prevail in the Standing Committee. Not only did they provoke the panelists to reflect on the political nature of education, but most significantly they were able to articulate how their commitment to social justice could be translated into engaging pedagogies.

One the biggest challenges for teacher educators and students is to make explicit the connections between the theoretical perspectives on issues of social inequality 
and educational disadvantage, and the realities of classroom practice. To paraphrase one of Cochran-Smith's undergraduate students, "What does teaching for social justice really mean? What do you actually do with the students?" (Cochran-Smith, 1999, p. 115). The student witnesses in the inquiry did address these questions and gave strong testimony to the value of sociological studies that encouraged critical reflection and an understanding of the social, political and economic factors that impact on education. They were able to show that becoming an effective teacher in disadvantaged schools extended well beyond technical competence to encompass an understanding of socio-cultural practices and beliefs in local communities.

Although their contributions were acknowledged in the footnotes of the report of the Committee (Hartsuyker, 2007, pp.45-46) their perspectives on social justice did not find their way into the text. In fact, the report largely sidestepped questions of educational philosophy, course content and teaching methods, other than to suggest that much more evidence-based and longitudinal research was needed to determine the effectiveness of different approaches to teacher education. There were few, if any, references to social justice, equity and educational disadvantage, and the report left unchallenged traditional conceptions of teachers' work. However, the report highlighted a need for more direct links between theory and practice in teacher education courses, and recommended a national Clearing House for Educational Research. These proposals, together with funding recommendations and measures to increase the diversity of the current teacher education student population, especially Indigenous students, provide some resources of hope for those seeking to improve the quality of teacher education. It remains to be seen if Federal legislators have the political will to adopt the many worthwhile recommendations in the report.

\section{Conclusions}

This paper has explored the notion of robust hope with reference to the ideal of socially just schooling. I have argued that the persistence of educational disadvantage and social inequalities in neoliberal times demands a concerted effort on the part of education systems, schools and teacher education institutions, to speak out against oppressive policies and to reinsert social justice principles, values and practices into all aspects of curriculum policy and planning. My thinking has been guided by a vision of an egalitarian society and a fairer school system, but it is also grounded in a notion of robust hope that recognises the practical possibilities and the limits of social change and school reform.

At the core of this notion is the issue of human agency. There has been a tendency in some quarters to conceive of policy as some centrally determined, authoritative process that sets rigid boundaries around what schools and teachers can and cannot do. However, the Wattle Plains study showed that, in spite of the coercive nature of some mandated education policies, it is still possible for teachers and school 
communities to exercise a degree of autonomy in the selection of resources and strategies to promote socially just curriculum. Fundamentally, it is teachers who mediate the relationships between the curriculum and students in the classroom, and it is their efforts that are likely to make the most immediate difference for students.

However, the study also showed there are limits to what can be achieved within the perimeters of local schools. Because the fates of schools and their communities are inextricably linked, school reform needs to proceed in tandem with community rejuvenation. Widespread and more enduring reform for social justice is only achievable through collective action involving a broad range of educational institutions and community coalitions. The imperative to move beyond "romantic localism" led me to propose a set of strategies and resources to guide the development of a revitalised commitment to social justice in education policy and practice. The essential components of this framework for robust hope comprised a critique of current arrangements, a vision for the future, and political and organisational strategies to move to a preferred future.

There can be little doubt of the enormity of the task of reclaiming the utopian imagination for more socially just schooling in the present political climate. The term "social justice" has been largely expunged from the policy discourse, and prominent Coalition ministers have gone to some lengths to discredit the social justice agendas of schools, teacher education programs and State education bureaucracies. As was revealed in the graduate students' submissions to the teacher education inquiry, the idea of learning to teach for social justice runs counter to popular conceptions of the role of teacher education courses which many believe should be aimed exclusively at producing competent and skilled practitioners. A tendency to view teaching as technical, rather than transformative work, clearly militates against the possibility of developing critically reflective teachers who see themselves as agents of social change.

Perhaps the ideal of socially just schooling will always remain a utopian dreamsomething to struggle for, rather than an achievable goal. In spite of the oppressive nature of many neoliberal reforms, hegemony is not complete. Through collective agency, educators still have a degree of autonomy to pursue alternative, progressive and emancipatory practices. This paper has shown that there are resources of hope to promote the ideal of socially just schooling.

\section{Notes on Contributor}

Peter McInerney is a Research Associate at the University of Ballarat. Email: p.mcinerney@ballarat.edu.au. His research interests span the areas of teachers' work, school reform, social justice and critical ethnography.

\section{References}

Apple, M. (1996). Remembering capital. Fournal of Curriculum Theory, 11(1), 113129.

Apple, M., \& Beane, J. (1995). Lessons from democratic schools. In M. Apple, \& J. Beane (Eds.), Democratic schools (pp. 101 105). Alexandrina: Association for Supervision and Curriculum Development. 
Benhabib, S. (1986). Critique, norm and utopia. New York: Columbia University Press.

Berliner, D. (2006). Our impoverished view of educational reform. Teachers College Record, 108(6), 949995.

Brennan, F. (2006, January 23). What's lost in translation? The Age Melbourne, p. 13.

Brotherhood of St Laurence. (1990). Australians in poverty. Melbourne: Brotherhood of St Laurence.

Brotherhood of St Laurence. (2005). The Brotherhood's social barometer. Fitzroy, Victoria: Brotherhood of St Laurence.

Burgess, R. (1988). Conversations with a purpose. In R. Burgess (Ed.), Studies in qualitative methodology, 1, 137155.

Cochran Smith, M. (1999). Learning to teach for social justice. In G. Griffin (Ed.), The education of teachers ninety eighth yearbook of the national society for the study of education (Vol. 1, pp. 114 144). Chicago: University of Chicago Press.

Commonwealth of Australia. (2005). House of Representatives Standing Committee on Education and Vocational Training. Canberra: Official Committee Hansard. Retrieved February 2, 2007, from http://parlinfoweb.aph.gov.au/piweb/view document.aspx?id=56911\&table=COMMREP.

Connell, R. (1993). Schools and social justice. Leichardt: Pluto Press.

Connell, R. (1998). Schools, markets, justice. In A. Reid (Ed.), Going public. West Deakin: Australian Curriculum Studies Association.

Freire, P. (1994). Pedagogy of hope. New York: Continuum.

Gale, T., \& Densmore, K. (2000). fust schooling. Buckingham, PA: Open University Press.

Giroux, H. (2005). The conservative assault on America. Cultural Politics, 1(2), 139164.

Giroux, H. (2006). Stormy weather. Boulder: Paradigm Publishers.

Goodman, J. (1992). Elementary schooling for critical democracy. New York: State University of New York Press.

Grieg, A., Lewins, F., \& White, K. (2003). Inequality in Australia. Cambridge and New York: Cambridge University Press.

Halpin, D. (1999). Utopian realism and a new politics of education. Fournal of Education Policy, 14(4), 345361.

Halpin, D. (2003). Hope and education. London: RoutledgeFalmer.

Harradine, J. (1996). What research tells us about school reform. National Schools Network Newsletter, 2(2), 45.

Hartsuyker, L. (House of Representatives Standing Committee on Education Vocational Training.) (2007). Top of the class: Report of the inquiry into teacher education. Canberra: The Parliament of the Commonwealth of Australia.

Kemmis, S. (1994). School reform in the '90s: Reclaiming social justice. Conference of the Touchstones of the Socially Just School. Adelaide: Flinders Institute for the Study of Teaching.

Lingard, B. (1994). The struggle for more socially just schooling. Queensland Teachers Union Professional Magazine, 12(1), 15.

Mac an Ghaill, M. (1996). Sociology of education, State schooling and social class. British fournal of Sociology of Education, 17(2), 163176.

May, S. (1994). Making multicultural education work. Adelaide: Multilingual Matters.

McInerney, P. (2004). Making hope practical. Flaxton, Queensland: Post Pressed.

McLaren, P., \& Giarelli, J. (1995). Critical theory and educational research. Albany, NY: SUNY Press.

Nieto, S. (2000). Placing equity at the front and centre. Fournal of Teacher Education, 51(3), 180187.

Reid, A. (2005, September 4 10). Creating an educational crisis. Independent Weekly, Adelaide, p. 9.

Shor, I. (1992). Empowering education. Chicago: University of Chicago Press. 
Shor, I. (1996). Education is politics: Paulo Freire's critical pedagogy. In P. McLaren, \& P. Leonard (Eds.), Paulo Freire: A critical encounter. London: Routledge.

Shor, I., \& Freire, P. (1987). A pedagogy for liberation: Dialogues on transforming education. Massachusetts: Bergin \& Garvey.

Smyth, J. (Ed.) (1993). A socially critical view of the self-managing school. London: Falmer Press.

Smyth, J., \& Hattam, R. (2004). 'Dropping out', drifting off, being excluded. New York: Peter Lang.

Smyth, J., \& Angus, L. (2006). Individual, institutional, and community capacity building in a cluster of disadvantaged schools and their community. Canberra: Funded project proposal to the Australian Research Council, Discovery Grants Scheme.

Smyth, J., Angus, L., Down, B., \& McInerney, P. (2006). Critical ethnography for schools and community around social class differences affecting learning. Learning Communities: International fournal of Learning in Social Contexts, 3, 121-152.

Smyth, J., \& McInerney, P. (2006). Teachers in the middle. New York: Peter Lang.

Stilwell, F. (2000). Changing track. Annadale, NSW: Pluto Press.

Troyna, B., \& Vincent, C. (1995). The discourse of social justice in education. Discourse Studies in the Cultural Politics of Education, 16(2), 149-166.

Tyack, D., \& Cuban, L. (1995). Tinkering towards utopia. Cambridge, MA: Harvard University Press.

Whitehead, K. (2007). Student teachers. Their disruptive voices. Unpublished paper presented at the social justice and the teachers of tomorrow symposium, Adelaide, Flinders University.

Williams, R. (1989). Resources of hope. London: Verso. 